\title{
RELAÇÕES ENTRE CORPO E MÁSCARA NO CARNAVAL DE VENEZA ${ }^{1}$
}

Recebido em: $13 / 05 / 2014$

Aceito em: 22/11/2014

\author{
Vitor Hugo Marani ${ }^{2}$ \\ Larissa Michelle Lara ${ }^{3}$ \\ Universidade Estadual de Maringá - UEM \\ Maringá - PR - Brasil
}

RESUMO: Esta investigação teve por objetivo analisar como foliões trajados tradicionalmente no carnaval de Veneza concebem a máscara e como a relação corpomáscara é construída no tempo-espaço da festa. $\mathrm{O}$ estudo materializa-se com a imersão no cotidiano veneziano e nas festividades carnavalescas, nas quais o costume de adornar-se com máscaras compõe a festa. Observações e entrevistas foram os instrumentos realizados nessa pesquisa, a qual contou com a participação de cinco foliões trajados tradicionalmente em locais públicos da cidade. Os dados apontam para a dialética entre corpo e máscara: ora tal relação se expressa pela busca de experiências relacionadas à dimensão lúdica, à construção estética como via para se alcançar o protagonismo na festa e à representação teatral; ora ela ocorre a partir da lógica "máscara produto", repleta de significados relacionados à dimensão turística que vê na máscara o potencial de consumo.

PALAVRAS CHAVE: Corpo. Festa. Cultura.

\section{RELATIONS BETWEEN BODY AND MASK IN CARNIVAL OF VENICE}

ABSTRACT: This research aimed to examine how traditionally costumed revelers at the Venice Carnival conceive mask and mask-like body relationship is built on the timespace of the party. The study materializes with immersion in the everyday and the Venetian carnival festivities in which the custom of adorning themselves with masks composed the party. Observations and interviews were conducted in this research instruments, which included the participation of traditionally costumed revelers five public places in the city. The data point to the dialectic between body and mask: now this relationship is expressed by the search for experiences related to playful dimension to the aesthetic construction as a means to achieve the leadership in the party and theatrical representation; sometimes it happens from logic "mask product," full of meanings related to tourism dimension that see in the mask the potential consumer.

\footnotetext{
${ }^{1}$ Este texto é resultante de estudos desenvolvidos junto ao Programa de Pós-Graduação Associado em Educação Física UEM/UEL, os quais culminaram na dissertação de Mestrado intitulada "O corpo e a máscara no Carnaval de Veneza", defendida em fevereiro de 2015.

2 Mestre em Educação Física pelo Programa de Pós-Graduação Associado em Educação Física UEM/UEL - Integrante do Grupo de Pesquisa Corpo, Cultura e Ludicidade (DEF-UEM-CNPq).

3 Doutora em Educação pela Universidade Estadual de Campinas. Docente do Programa de PósGraduação Associado em Educação Física UEM/UEL - Líder do Grupo de Pesquisa Corpo, Cultura e Ludicidade (DEF-UEM-CNPq). Bolsista Produtividade em Pesquisa pela Fundação Araucária-PR.
} 
KEYWORDS: Body. Party. Culture.

\section{Introdução}

A investigação proposta neste texto revela inquietações acerca do corpo, da máscara e suas representações junto a foliões mascarados que compõem o carnaval italiano de Veneza. A eles é atribuída a função de significar e (re)significar a máscara, trajando-a como parte do corpo e dando-lhe "movimento" no cenário festivo, fato que traduz a constituição da relação entre a máscara e o corpo, o que pode culminar num jogo de vivências corporais, transpondo formas racionais ligadas ao intelecto e ao lógico em direção à razão sensível e expressiva.

O interesse por esse desenvolvimento temático deu-se a partir de imersões na cidade de Veneza, no período carnavalesco, sobretudo em meio às motivações que conduziam à necessidade de conhecer o festejo que atribui nova silhueta à cidade. $\mathrm{O}$ percurso realizado até a Praça de São Marcos, antes composto por olhares direcionados aos pontos turísticos venezianos, naquela ocasião ganhava nova composição: sujeitos mascarados e em grande parte fantasiados tomavam conta das ruelas, o que evocava novas cores e brilho ao cenário. A passagem por esses personagens dava-se juntamente à circulação dos turistas, o que acabava por mesclar o corrente à fantasia, gerando novas experiências estéticas aos que viviam o decoro composto pela festa, e àqueles que, ao observarem e fotografarem, deslumbravam um outro contexto proposto pelo carnaval.

É no carnaval veneziano, palco dessa pesquisa, que corpos fazem da máscara o adereço principal para brincar nas ruelas e praças da cidade, o que sugere a atribuição de nova linguagem ao corpo. Nas palavras de Vasconcellos (2010), a máscara é objeto que representa a figura simbólica da linguagem cênica e constitui-se como peça do vestuário que cobre, parcial ou totalmente, o rosto do sujeito que a utiliza, transformando-o a 
partir de características e preceitos. Utilizada também para esconder o rosto, a máscara, para Pavis (2011), reflete a renúncia voluntária à expressão psicológica, fazendo com que o sujeito que a utiliza saiba desfrutar de seu corpo para programar a perda de expressão, traduzindo seus sentimentos de maneira amplificada, exagerando em seus sentidos criativos e expressivos.

Logo, o corpo mascarado, ou seja, o corpo configurado pelo ato de mascarar-se, assume normas consolidadas a partir de dinâmicas culturais que dão sentido à sua própria deflagração, o que abre possibilidades para se pensar os significados que se inscrevem na conduta dos sujeitos no carnaval. Tais condutas, orientadas pelo uso das máscaras da cultura local, representam um costume presente na atualidade, mas que possui suas raízes históricas em carnavais venezianos datados do início do século XIV. Por isso, entender a máscara e o corpo como integrantes de anseios investigativos atuais não se constitui como algo ultrapassado, uma vez que, em face das transformações ocorridas na dinâmica do carnaval veneziano contemporâneo em relação ao seu surgimento, o costume de adornar-se com máscaras encontra-se ainda em evidência durante o período festivo.

Ao estudar a festa, Rosa (2002) a traduz como conteúdo da cultura no lazer, observando seu dinamismo no tocante às relações, aos interesses e aos valores que cunham a pluralidade da cultura. Ainda, a compreende como tempo-espaço para expressar-se, rebelar-se, manifestar-se, reivindicar, entre outras. Para a autora, as festividades geram a necessidade por busca de ações que transcendam os gestos institucionalizados, possibilitando aos indivíduos presentes nesse tempo-espaço específico adotar novos papéis a partir de personagens potencializados mediante seu imaginário. Brandão (1989), nessa mesma perspectiva, vê a festa como tempo-espaço de 
ruptura relacionado à vida diária e que possibilita a quebra de regras que normatizam a sociedade, fazendo com que a lógica instaurada seja infringida.

Ao pensar a festa como propulsora de experiências que corroboram um novo instaurar cotidiano vivido a partir de "outra" lógica do humano, é possível perceber que a máscara pode servir como meio para acentuar tal experiência. Isso se deve ao fato da máscara, no imaginário social, estar intimamente ligada às formas de disfarce da expressão e da identidade, fazendo com que o sujeito mascarado opte por transitar por caminhos que, comumente, por estar com o rosto disponível às pessoas, dificilmente conseguiria percorrer. Logo, a investigação proposta objetiva analisar como foliões trajados tradicionalmente no carnaval de Veneza concebem a máscara, e como a relação corpo-máscara é construída no tempo-espaço da festa. Para tanto, a fase exploratória foi composta pelo delineamento teórico acerca da representação da máscara, especialmente no carnaval veneziano.

O desenvolvimento metodológico do estudo, embora não pautado pela etnografia proposta por Geertz (2008), recebeu algumas de suas orientações no tocante à narrativa da cultura de um determinado grupo social por meio da descrição das estruturas de significados, o que permitiu a aproximação junto às pessoas, às situações e aos eventos que compunham o carnaval, principalmente a partir de ruelas e praças da cidade, as quais traduzem o espaço posto para os foliões brincarem na festa.

A interlocução com esses sujeitos deu-se a partir da realização de entrevistas com roteiro semiestruturado e da observação participante realizadas durante a imersão no carnaval de Veneza do ano de 2013. Ao todo, cinco foliões escolhidos de maneira aleatória integraram a pesquisa seguindo critérios mínimos de seleção, dentre os quais, estar trajado com máscara e figurino que fizessem referência ao carnaval veneziano; comunicar-se em italiano, inglês ou português; e, por fim, ter disponibilidade em meio à 
festa. Após a realização das entrevistas, os depoimentos gravados foram transcritos e receberam codificações a partir da letra "F", sendo numerados sequencialmente, bem como traduzidos da língua nativa para a língua portuguesa.

Para a análise das informações advindas das entrevistas, três momentos foram necessários. O primeiro deu-se por meio da primeira leitura, num sentido amplo, a fim de retomar as informações decorrentes das entrevistas. O segundo foi realizado a partir da leitura dos textos de modo a identificar aspectos específicos em atendimento ao objetivo do estudo, com o intuito de extrair eixos temáticos das falas dos entrevistados, o que consistiu na leitura detalhada de todo o material transcrito e na identificação de palavras e conjuntos de palavras que tivessem sentido para a pesquisa. No terceiro momento, buscou-se sintetizar os dados de maneira a unir os eixos temáticos que tivessem afinidade, atentando-se a novos eixos decorrentes desse processo. A partir desse momento os excertos foram agrupados, o que contribuiu para a organização dos eixos de análise, fazendo com que o desenho analítico tomasse forma.

O recurso imagético obtido por meio das fotografias realizadas via câmera fotográfica também serviu como suporte para que, posteriormente, o campo investigativo fosse formado, pois, como afirma Castro Júnior (2014), a fotografia auxilia na retomada das lembranças e episódios decorrentes das imersões no contexto da festa, bem como na elucidação e ilustração de muitos aspectos que, por meio de palavras, não conseguem ser traduzidos, contribuindo com a revelação de sentidos que perpassam a imagem.

Do diálogo entre evidências empíricas (observações registradas em diário de campo, depoimentos gravados e recurso imagético) e literatura disponível e acessível, bem como os pressupostos teóricos eleitos para a pesquisa, serviram como suporte para a edificação das teias analíticas. Logo, o desenvolvimento da investigação, em 
atendimento aos objetivos propostos, à problemática da pesquisa e à sua orientação metodológica, refletiu na possibilidade de traçar olhares em relação ao fenômeno, entendendo que não são únicos, mas alcançados a partir dos referenciais teóricos utilizados. Em síntese, a temática nos auxilia na compreensão de como o carnaval atua como tempo-espaço de jogo para os sujeitos que o vivem. Tais apontamentos possibilitam a construção de um panorama que leva a diálogos com diferentes festejos, sobretudo aqueles que tenham a máscara como premissa para brincar, encontrando nela mecanismos necessários para vivenciar diferentes racionalidades.

O texto em questão incursiona por dados históricos acerca do carnaval de Veneza e pela festa contemporânea, culminando no diálogo com foliões que se tornam protagonistas da pesquisa na tentativa de apreender como eles significam a máscara nesse tempo-espaço festivo. Dessa relação decorrem dados que indicam como se constroem os elos entre corpo e máscara nesse carnaval, os quais contribuem com reflexões acerca da construção do corpo brincante carnavalesco.

\section{O Carnaval de Veneza}

Desde o século XIII, viajantes e cronistas relatam fatos recorrentes das festividades carnavalescas nas cidades de Florença, Roma, Nápoles, Veneza e outras que compunham a região Mediterrânea. Tais eventos assemelhavam-se, em especial, àqueles que ocorriam na periferia, caracterizados por Burke (2002) face o consumo excessivo de bebidas e comidas, o insulto aos vizinhos e canções de músicas de cunho sexual e/ou político. Entretanto, para além das similaridades, cada cidade apresentava eventos específicos, a exemplo dos desfiles de carros alegóricos na cidade de Florença e das corridas ao longo do corso em Roma. Já em Veneza, o doge - magistrado supremo da antiga república Veneziana - e seus súditos permaneciam na janela do palácio na 
Praça de São Marcos, enquanto animais eram caçados, executados e, por fim, distribuídos na forma de carcaças aos nobres da cidade.

A partir do século XVI, espetáculos compostos por danças, cantorias, peças de teatro, bailes e banquetes nos palácios, bem como outras atividades na zona periférica, como corridas de barco nos canais pluviais e corridas de touro na Ponte del Rialto são introduzidas no Carnaval Veneziano. É nesse período que, segundo o autor, máscaras e fantasias são usadas pelos foliões e descritas como componentes da festa, onde comumente eram empregadas máscaras da commedia dell'arte, bem como de sujeitos da sociedade, como reis, camponeses e outros.

Na temporada de festa - compreendida entre a comemoração de São Stefano, no dia 26 de dezembro, e a terça-feira que antecedia a Quaresma - Veneza tornava-se o local dos excessos e da permissividade, fazendo com que a ausência de limites se refletisse na cultura local, a exemplo de atos de violência entre os foliões, tanto simbólica quanto real, ocasionando várias mortes no período carnavalesco. Esses episódios fizeram com que alguns elementos do Carnaval desaparecessem ao final do século XVI, entre eles o tripudio - dança tradicional realizada nas festas daquele período; o repúdio àqueles que se vestiam como a nobreza; o desconforto em relação à execução dos animais nas praças; e, por fim, a ausência do doge em seu camarote real para contemplar a festa (BURKE, 2002).

Todavia, as festividades não se interromperam mas, pelo contrário, evidenciaram o potencial turístico da cidade à época. Com tantos visitantes, Veneza foi criando mecanismos para recebê-los, fazendo com que a comercialização na cidade crescesse ao longo dos anos. O comércio se dava a partir do aluguel de quartos, barcos, guias para demonstração dos pontos turísticos e ainda, o emprego de muitos artistas profissionais, como acrobatas, equilibristas, leitores de sorte, entre outros. O fluxo turístico, segundo 
Burke (2002), dava-se pelo fato da cidade embarcar viajantes em direção à Terra Santa, que enquanto esperavam o andamento de seu trajeto aproveitavam os deleites da cidade.

O carnaval em Veneza atraía milhares de turistas, principalmente no século XVII. Os registros que constam na obra de Burke (2001) relatam a visita de príncipes estrangeiros ao carnaval, o que supõe a hospitalidade e os prazeres propostos aos visitantes. Ainda, o autor afirma que a quantidade de turistas nas festividades transformou a cidade num espaço de lazer e prazer. Tal fato contribuiu para que os eventos se tornassem mais comerciais e profissionais, o que abriu espaço para que artistas desenvolvessem suas atividades junto às festividades públicas e privadas.

A partir do século XVIII, o sentido do carnaval de Veneza havia mudado completamente, o que levou à associação da festa aos prostíbulos e aos cassinos presentes na cidade. Tal ideia aparece de modo direto em Zorzi (2011) ao discorrer sobre os acontecimentos históricos em Veneza, pontuando o carnaval de 1796 como o mais desenfreado ocorrido na história da cidade. Porém, Madden (2010) relata que com a queda da República por conta da ocupação da tropa de Napoleão Bonaparte, houve o desaparecimento do elemento central da festa: a permissão do uso de máscaras e, posteriormente, a permissão à festa. Bressanello (2009), por sua vez, destaca que, em 1797, as festividades foram encerradas, fazendo com que a festa não passasse de simples recordação durante quase dois milênios.

O carnaval veneziano, segundo Bressanello (2009), retoma suas raízes históricas oficiais somente em 1980, renascendo em meio à contemporaneidade. Nesse ano, houve uma programação oficial que convidava os venezianos a passarem o carnaval na Praça São Marcos, o que propunha a vivência da antiga tradição da República Veneziana. As atividades apresentaram sucesso entre moradores e turistas, o que colaborou para que, 
nos anos sucessores, houvesse a realização do carnaval de Veneza como festa tal qual é concebida na atualidade.

Fonte de interesses e aspirações, a cada ano a festa procura recorrer a inovações, principalmente no que toca à programação, à oferta de entretenimento e à temática do evento em geral. Tais aspectos comumente são anunciados no site oficial do evento ${ }^{4}$ com certa antecedência e trazem consigo informações acerca das escolhas feitas pela organização da festa, gerida pela assessoria de produção cultural da prefeitura de Veneza, como trata Bressanello (2010). Entretanto, mesmo com mudanças temáticas no corpo da festa, a dinâmica procura atender a um formato padrão, o que implica em pensar numa grande festa a céu aberto na Praça São Marcos, edificada principalmente pela construção de um grande palco no qual as apresentações artísticas ocorrem, bem como em pequenas manifestações realizadas em locais isolados, sejam elas livres ou com programação oficial.

A partir dessa dinâmica, a programação da festa organiza-se para atender os turistas por meio de uma extensa lista de atividades ${ }^{5}$, abarcando quase 20 dias de composições festivas baseadas na data proposta do carnaval de cada ano. Em 2013, a festa foi iniciada no dia 15 de fevereiro e encerrada no dia 4 de março, regida pelo tema das cores. A temática foi escolhida porque Veneza era considerada uma das poucas cidades em que o espectro de cores refletia-se nas águas dos canais durante o período carnavalesco.

Mesmo com vários dias de carnaval relacionados na programação foi possível notar que a concentração das pessoas na cidade ocorre, principalmente, entre a sextafeira da semana que antecede o carnaval e a terça-feira, dia do próprio carnaval. Nesse período, a cidade se transforma. Todos os espaços que conduzem até a Praça São

\footnotetext{
${ }^{4}$ Disponível em: $<$ http://www.carnevale.venezia.it/>. Acesso em: nov. 2014.

${ }^{5}$ As atividades podem ser consultadas no site $<$ www.carnavale.venezia.it/programma $>$. As apresentações envolvem peças teatrais, musicais e dançantes e todas são apresentadas no grande palco.
} 
Marcos onde acontecem os desfiles de máscaras e os eventos mais importantes, em período de festa ficam lotados e o movimento na cidade faz com que o fluxo seja mais lento que o normal, uma vez que a Praça é a meta da maioria dos foliões que se deslocam até a cidade.

Na Praça São Marcos ocorre a realização de alguns episódios que demarcam o acontecimento do carnaval, a exemplo do Voo do Anjo, que marca a abertura oficial do carnaval de Veneza. A cena é composta por uma personagem - a Colombina - que é responsável por alçar voo da Torre del Campanile até a estrutura do palco montado na grande praça a partir do cabo que liga as duas estruturas. Em suas mãos, a dama segura um cetro que deve ser entregue à figura do Doge quando chega ao palco que, por sua vez, declara a abertura oficial do evento na Praça. Geralmente essa demonstração é realizada no domingo que antecede a sexta-feira gorda de carnaval e faz com que a Praça seja totalmente tomada por turistas e foliões mascarados.

Nesse interim, mascarados aproveitam para realizar seus passeios na Praça São Marcos e consagram a exposição de suas máscaras e seus trajes que, comumente, auxiliam na construção de dado personagem a partir de processos criativos. Tais mascarados preocupam-se em ocupar os diferentes espaços da Praça, o que auxilia na distribuição de pessoas no local, uma vez que muitos sujeitos estão no carnaval para desfrutar da experiência de observação da festa e das criações decorrentes dela. Além disso, aqueles que estão presentes na festa podem aproveitar as várias atividades no espaço da Praça São Marcos. Dentre elas está a possibilidade de visitar os monumentos dispostos na Praça, sentar-se para tomar café, apreciar a beleza do Mar Adriático que banha Veneza ou até mesmo visitar as sacadas da Igreja São Marcos, as quais oferecem visão panorâmica da festa. 
Entre tantas pessoas mascaradas era possível visualizar inúmeras figuras de máscaras, tanto aquelas que compunham a tradição de máscaras venezianas, principalmente a Bauta, o Medico della peste e algumas máscaras da Commedia dell'arte, como o arlechino e o brighela, quanto máscaras que não possuíam características voltadas à tradição, mas que traziam algo de peculiar. As últimas, por sua vez, eram máscaras adaptadas e pareciam ser criadas a partir de novas ideias dos próprios foliões.

No carnaval veneziano, palco investigativo desse estudo, a máscara aparece como elemento que compõe a festa, o que permite aos sujeitos um brincar que transparece em meio à desordem e ao oculto e, por isso, desperta inquietações àqueles que o observam. As evidências empíricas - observações em campo e depoimentos gravados - em diálogo com a literatura disponível aos pesquisadores, constituem um panorama que visa compreender de que maneira o carnaval atua como tempo-espaço festivo que fomenta a relação entre corpo e máscara nos sujeitos que o brincam, bem como as representações decorrentes dessa relação.

\section{Entre corpos, máscaras e representações}

A apresentação de recorte das falas dos foliões entrevistados no cenário carnavalesco emerge como fundamental à discussão, sendo importante ressaltar que a construção teórica aqui realizada parte de delimitações dessas falas advindas principalmente das circunstâncias nas quais as entrevistas ocorreram: a praça repleta de turistas (o que gerava muito barulho) e de muitos fotógrafos (que quase não permitiam a realização das entrevistas), além de poucos foliões mascarados, o que remete ao esvaziamento de pessoas paramentadas no carnaval para brincá-lo. 
A partir do jogo dos mascarados nota-se a manifestação do lúdico no carnaval veneziano por meio da expressão de elementos relacionados à diversão e à criação de um universo imaginário que se constrói para a efetivação de uma atmosfera amistosa entre aqueles inscritos na festa. Nessa atmosfera, Bakhtinm (2010) dá à máscara posição fundamental na atuação como artefato que, além de almejar o disfarce da personalidade, acaba por revelar ludicamente uma identidade. Na visão desse autor, antes de se ter um rosto escondido, tem-se uma personalidade a ser manifestada por meio do universo lúdico. Tal universo é representado a partir de sentimentos relacionados à alternância e renovação, capazes de traduzir a realização do jogo das avessas e das permutas constantes.

Nessa direção, encontra-se a figura do mascarado que, em meio a processos normativos da vida diária, desfruta do tempo-espaço carnavalesco como meio para vivenciar a ludicidade a partir do jogo constituído pelo representar em máscaras. A percepção do lúdico nessa esfera da festa dá-se pelos dizeres de Huizinga (2004) que, ao tratar da manifestação lúdica, destaca sua existência em múltiplos campos da sociedade, bem como aponta para a constituição de uma realidade autônoma em que o sujeito brincante insere-se no momento do jogo.

Vestir a máscara durante o período carnavalesco, para eles, corresponde ao ato de entregar-se às vontades e desejos nem sempre possíveis quando estavam com o rosto à mostra, faltando-lhes coragem por conta da insegurança, timidez ou vergonha. Nos dizeres de Caillois (1990), a máscara, por assegurar o anonimato, abriga e protege, fato que dispõe ao sujeito que faz seu uso, liberdade ostensiva dos constrangimentos advindos da sociedade, representando o meio de transgredir os próprios limites. Isso indica que as máscaras vingam-se do decoro e da contenção obedecidos ao longo do ano e tudo que há de ordenado no mundo é passageiramente abolido para surgir revitalizado. 
A máscara pode ser vista como possível forma de alcançar esse fim numa busca constante, para alguns, da transgressão da repressão social mesmo que de forma tênue, uma vez que, antes de se pensar na máscara é necessário recordar que o sujeito, ao dar vida a ela, tem consciência das possibilidades de ações permissíveis em meio ao convívio social. Tal fato pode ser entendido a partir das contribuições de Freire (2005) ao recordar que os sujeitos, mesmo quando imersos no ambiente lúdico, mantêm certa lucidez, o que sustenta transgressão à realidade e permite o desenvolvimento da imaginação, bem como o afrontamento com as barreiras do mundo real.

Ela também se revela como jogo, haja vista que possibilita ao folião expressar-se na transgressão dos limites do mundo adulto, no campo coletivo e marcado por elementos lúdicos, como revela o relato de F2.

O significado da máscara para mim é fundamentalmente um jogo. Te permite fazer, talvez, tudo aquilo que não pode como adulto, e por ocasião do Carnaval, todos podem jogar juntos, divertindo-se, uma alegria de cores. Ser aquilo que não pode ser durante o resto do ano. (F2)

Nesse sentido, o ato de vestir as máscaras pode ser compreendido a partir de uma dinâmica que lhe é própria, pensado a partir da definição de jogo cunhada por Caillois (1990), pautada na ideia de atividade livre e voluntária; regulamentada ou fictícia; fonte de alegria e divertimento; ocupação separada do resto da existência; delimitação de um tempo e espaço próprios; incerteza do resultado final; e, por fim, atividade improdutiva. A relação entre tais elementos constrói-se a partir da visualização da máscara como artefato estético que orienta o corpo a novas experiências. Tais experiências são criadas pela figura do folião mascarado que, na condição de sujeito, sustenta sua ação quanto vestir ou não a máscara; desfruta da imaginação e da fantasia, o que o leva à ficção; alcança sentimentos como diversão e alegria por meio do processo de mascaramento; e, vive tempos-espaços que se edificam 
para além da vida diária, principalmente quando pensada a relação da máscara com o carnaval.

Para além da definição de jogo cunhada pelo autor, a classificação dos jogos idealizada a partir do "estado de espírito" daquele que joga, auxilia na compreensão da máscara como elemento lúdico no carnaval, principalmente a categoria Mimicry, que remete à representação, o que substitui as regras pelo sentimento do "como se" $\mathrm{e}$ desempenha, ao final, a mesma função. Caillois (1990) explica que o prazer vislumbrado pelo homem ao disfarçar-se, travestir-se ou usar uma máscara ocorre como réplica do mimetismo selvagem, ou seja, como forma de "mudar a aparência de quem usa e meter medo aos outros" (CAILLOIS, 1990, p. 40).

Para o sociólogo francês, o prazer nessa dimensão encontra-se relacionado ao fato de ser um outro alguém sem que a expectativa seja ludibriar realmente quem assiste, ou seja, simples e puramente, trata-se de um jogo. Nessa perspectiva, o jogador - que no carnaval assume a figura do mascarado - tem consciência de que as ações nesse tempo e espaço são simulações, pura atuação, e, é essa consciência, de acordo com Caillois (1990), que afasta o sujeito da sua vida comum, transpondo-o a uma irrealidade radical.

As relações entre o ato de mascarar-se no carnaval italiano e a tipologia Mimicry proposta por Caillois (1990) transparecem por meio da dinâmica em que "o sujeito joga a crer, a fazer crer a si próprio ou a fazer crer aos outros que é outra pessoa. Esquece, disfarça e despoja-se da sua personalidade para fingir outra" (CAILLOIS, 1990, p. 39). Ao invés da máscara e do disfarce serem adereços, fazem parte do corpo brincante. De acordo com o autor:

"no carnaval, a máscara não pretende fazer crer que se é um verdadeiro marquês [...] mas sim meter medo e tirar proveito da desordem ambiental, ela mesma resultando do facto de a máscara dissimular o personagem social e libertar a verdadeira personalidade" (1990, p. 42). 
Daí a necessidade de aceite temporal de uma ilusão, sobretudo quando se encarna um personagem ou comportamento determinado.

Outra característica que evidencia a relação entre a tipologia Mimicry e o costume de adornar-se com a máscara diz respeito à invenção constante, atribuída tanto àqueles que representam em meio ao cenário festivo, quanto aos espectadores que aceitam à ilusão proposta. Aos primeiros, Caillois (1990) discorre acerca da necessidade em fascinar quem lhe assiste no intuito de que o espectador não recuse o papel interpretado pelo mascarado. O fascínio almejado pelo jogador apresenta-se, para os sujeitos entrevistados, como composição estética na condição de personagem principal da festa. As evidências, por meio das entrevistas, demonstram a preparação dos sujeitos na construção da máscara e da vestimenta para que o carnaval seja palco de momentos de fotografia, filmagens e representação constante, como afirma F4: "A máscara para mim é um espetáculo. Sem ela tenho vergonha de ser fotografada”.

A máscara também pode conter em si representações da arte teatral, como observado em Veneza, momento em que muitas máscaras estavam acompanhadas dos indumentos completos de dado personagem da Commedia dell'Arte - teatro popular improvisado, desenvolvido na Itália no século XV - como o Medico de la Peste, a Bauta, o Arlecchino, o Pantalone e o Brighella, o que remete à ideia de que os sujeitos que se utilizam do traje completo respeitam o jogo e encarnam a figura dramática. Alguns, por exemplo, recusam-se a estabelecer diálogo com os turistas e, geralmente, fazem uso dos monumentos da praça para comporem a paisagem, o que reforça uma construção estética peculiar, a exemplo do folião que se utiliza do pombo para compor a cena e do folião que se utiliza das portas e escadarias do Palácio Ducal para seu jogo cênico, como ilustra a Figura 1. 


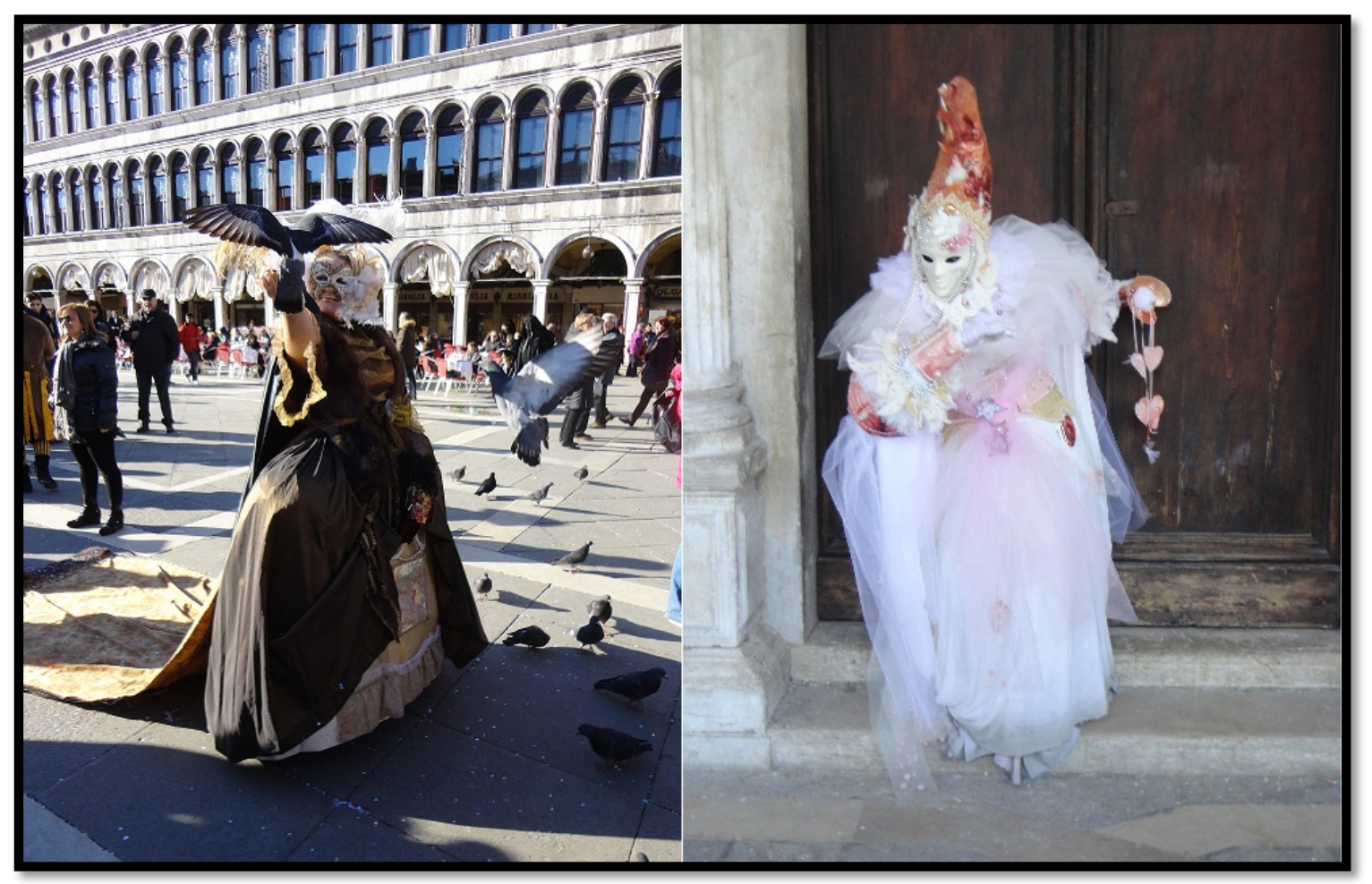

Figura 1 - Foliões trajados em meio à Praça San Marco.

O jogo cênico por parte desses foliões é constante e, a partir dele, observadores de todas as partes do mundo se sentem convidados a interagir com eles, o que origina novas experiências estéticas. Tais experiências, recorrentes do tempo-espaço carnavalesco, remetem à oposição entre o convencionado e o permissivo, o lógico e o sensível tanto para os que estão com a máscara, quanto para os que assistem à cena. Para Bracht (2003), ao traçar considerações entre o jogo e a ludicidade, transitar entre o lógico e sensível conota negação da coisificação humana, própria da racionalidade científica; é o momento em que o humano afirma-se como tal e salienta características desejáveis, como liberdade, prazer e criatividade. A dialética, segundo o autor, paira na questão central que envolve o universo lúdico: abarcar o mundo da sensibilidade ao mundo da razão, o que poderá aflorar relação de equilíbrio entre essas dimensões.

O corpo, como manifestação estética nesse contexto, assume a possibilidade de expressão por meio de um pensamento crítico fértil para reconciliar a dimensão sensível 
à racional. Em evidência, encontra-se em meio a esse mecanismo repressivo, que serve como ferramenta de expressão estética e que combate princípios de repressão encontrados na sociedade industrial. A dialética do corpo, seja na festa carnavalesca, seja no uso da máscara, emerge no envolvimento entre o sensível e o racional, o sentimento e o lógico, acarretando momentos em que, a partir das vivências do jogo, abram-se espaços para que os sujeitos, na condição de protagonistas, possam buscar comedimento que oriente suas ações cotidianas na vida corrente, transcendendo a razão posta como instrumental rumo à outra razão estética e expressiva.

As experiências estéticas observadas, construídas a partir das vivências dos sujeitos mascarados e que, demarcam a discussão sobre a reconciliação entre o sensível e o lógico despertavam atenção, em particular a vivência de um casal de foliões: um senhor trajado com roupas comumente femininas, vestido longo e colorido, mesclado a barba robusta, leque nas mãos e peruca. Ao seu lado, acompanhando-o, estava sua esposa, vestida com traje comumente utilizado por homens, como calça e paletó, como mostra a Figura 2. Os foliões relataram a diversão vivida durante o momento de inversão de papéis, quando suas personalidades afloravam-se a partir desse lado reprimido, ora feminino, ora masculino. 


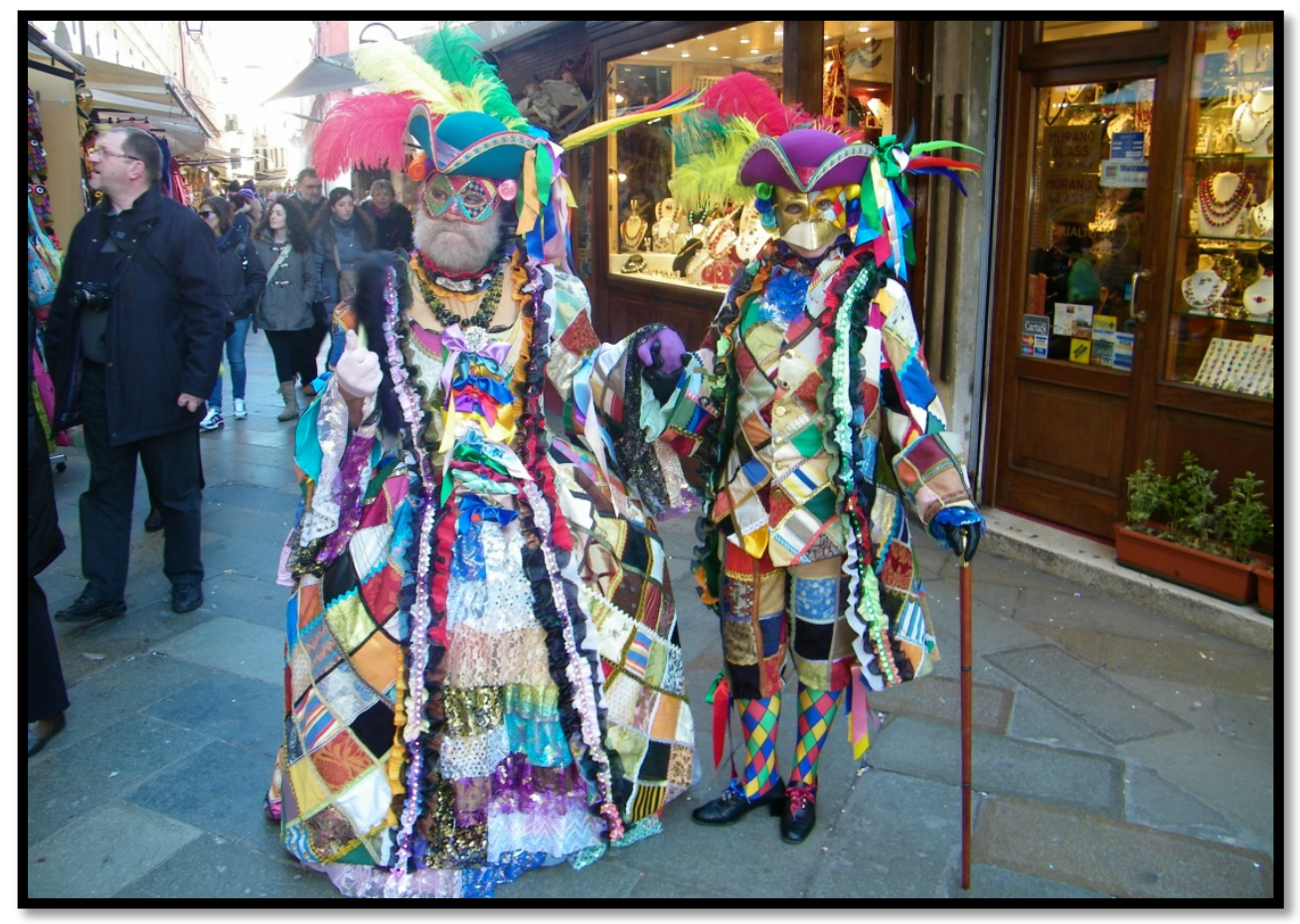

Figura 2 - Foliões trajados em meio à Praça San Marco.

Freire (2005), autor que discute o jogo, corrobora a discussão acerca do caráter libertino e nada disciplinado no ambiente lúdico, o que o torna antítese à burocracia social na qual os sujeitos estão submetidos. Essa transposição externa ao interior do humano constitui-se a partir da habilidade e capacidade de imaginar; e o jogo, nessa via, seria visto como transgressão dessa racionalidade, essencial para o desenvolvimento da imaginação nos seres humanos. Ainda, segundo Caillois (1990), as máscaras utilizadas no carnaval, por exemplo, não têm por objetivo fazer crer que se é realmente o personagem, mas sim, aproveitar a situação de desordem social para liberar, nos dizeres do sociólogo, a personalidade que lhe é verdadeira.

Segundo os depoimentos gravados, a máscara também suscita reflexão acerca da estratificação social. Nas festas do século XVII em Veneza, por exemplo, a nobreza misturava-se à plebe em meio ao carnaval, o que camuflava a ideia de classes sociais, uma vez que a distinção entre ricos e pobres, nobres e plebeus não era visibilizada. Como afirma um dos foliões: “A máscara oferece possibilidades às pessoas de mudarem 
seu jeito, de se misturarem. Não existe distinção. Os ricos tornam-se pobres e os pobres tornam-se ricos" (F5). Tal fato se dá pelo disfarce proposto pela máscara que, nas palavras de Reato (2001), traduz um vestir-se da própria imagem social, propiciando, ilusoriamente, a eliminação das distâncias sociais, fato que não poderia acontecer senão em tempos de festa.

Para os foliões participantes da pesquisa a máscara sugere campo fértil para se pensar em aspectos relacionados à liberdade, à dimensão lúdica, à construção estética como via para se alcançar o protagonismo na festa, à representação teatral e à eliminação de barreiras sociais durante o período festivo. Entretanto, a máscara também indica outras reflexões postas a partir das observações realizadas junto ao cotidiano festivo, bem como pela leitura de autores contemporâneos que elegem o carnaval veneziano e a máscara tradicional como temáticas investigativas. Embora os foliões não tenham apontado a máscara como forma de consumo em meio ao turismo da cidade, esse tema é recorrente em literatura que versa sobre o tema, bem como integra as observações realizadas pelos pesquisadores durante a estada em Veneza.

Os ditames comerciais, observados durante a imersão no contexto festivo, conduzem à reflexão de que a máscara, na relação com o corpo, não escapa ao seu caráter exibicionista e à constituição massiva da festa, constatação essa construída pelas observações realizadas em campo. Isso pôde ser percebido pela grande quantidade de foliões que buscavam, a todo o momento, a atenção dos fotógrafos que se faziam presentes no contexto festivo. Tal situação fazia com que o mascarado ficasse parte de seu tempo fazendo poses, ou seja, marcações paradas com o objetivo de fazer belas fotografias. Logo, exibir-se em público, gostar que as pessoas tirem fotos e posar para elas fazem parte da composição do mascarado. 
A sinalização de que a máscara pode ser compreendida pelo viés do consumo é tema recorrente no estudo de Reato (1998). Para o autor, atualmente, o costume de adornar-se com máscaras encontra-se bem distante daquele que compunha os anos de 1700 no Carnaval veneziano, principalmente no que diz respeito ao clima de festa e de divertimento. Ele relata que, no carnaval contemporâneo, transitar trajado pela cidade remete mais ao espírito de obediência aos modelos ditados pela sociedade consumista do que simplesmente ao ato de liberar a personalidade. Ainda, afirma que a máscara não finda com as hierarquias e comumente acarreta competição exibicionista com o objetivo de surpreender, o que reforça a distância social entre os foliões. A crítica amplia-se para a questão cultural a partir da influência da mídia de massa com a uniformização da cultura tradicional, o que traria como resultado sua falta de identidade e consciência.

Destaca-se a importância dessa visão, uma vez que, por ela, é possível entender os processos comerciais que envolvem a tradição e a figura do mascarado. Entretanto, não se pode descartar esses "usos", haja vista que eles auxiliam no desenvolvimento da própria festa, (re)inventando-a cada ano. Ainda, a consciência de que Veneza não é a única cidade que passa por tais impasses auxilia na compreensão de que as apropriações comerciais estão em todos os lugares, principalmente naqueles em que o turismo impera.

O corpo que brinca o carnaval veneziano manifesta-se a partir de diversas formas, resultado da relação estabelecida entre folião e máscara, o que gera novas experiências estéticas, a exemplo do jogo de personalidades (viver o que não podem viver em seu cotidiano, fantasiar, criar) que permite ao sujeito entreter e representar a partir do seu imaginário, premissa para constituição do sujeito como personagem principal da festa na cidade. A máscara, posta como adereço principal para as vivências carnavalescas, traduz alternativa à vida cotidiana, resultado da própria lógica das festas 
carnavalescas. Por isso, ela seduz os corpos inseridos nesse tempo-espaço, o que torna possível pensá-la como manifestação lúdica, ligada à representação e à mímica, capaz de estabelecer possíveis vias de reconciliação entre a dimensão sensível e a lógica dos brincantes, bem como gerar tensões com a racionalidade instrumental à medida que a nega e a assimila.

Por outro lado, outros olhares sobre corpo e máscara podem ser estabelecidos e emergem como essenciais ao diálogo, o que possibilita a visualização de aspectos que transpõem a ótica daqueles que brincam o carnaval da cidade. A construção de subjetividades padronizadas estabelecidas pela própria festa e sua subordinação aos moldes comerciais aparece como uma das discussões contemporâneas, evidenciada a partir de observações feitas do cotidiano festivo, o que demonstra consumos uniformizados, instaurados pela venda de máscaras que não dizem respeito à produção manufatureira dos artesãos venezianos. Por outro lado, o acesso à cultura industrial acaba sendo a via mais acessível, financeiramente falando, de obtenção da máscara, haja vista que o trabalho artesanal valoriza-se como produto artístico.

O corpo, inserido no contexto do carnaval veneziano, assume expressões evocadas, principalmente, por meio do uso da máscara. Por meio dela foliões representam, interpretam e vivem papéis que não se encontram relacionados à vida cotidiana. Todavia, os dados apontaram para o jogo de tensões construído pela divergência de informações entre as falas dos foliões entrevistados e a literatura clássica com as leituras realizadas de autores contemporâneos. Se por um lado a máscara representa experiências alheias ao corrente, por outro, está atrelada a interesses comerciais e lucrativos. Daí, a necessidade de se refletir acerca de como as experiências corpóreas dos foliões no carnaval italiano de Veneza são orientadas pelos aspectos de 
transposição do cotidiano e de enraizamento consumista, o que possibilita entender as diferentes dimensões orientadoras das relações entre corpo e máscara.

\section{Considerações finais}

A análise de como foliões trajados tradicionalmente no carnaval de Veneza concebem a máscara e como a relação corpo-máscara é construída no tempo-espaço da festa foi edificada a partir das evidências empíricas advindas das observações realizadas no cotidiano da festa, complementadas com as falas dos sujeitos brincantes. A partir daí, desdobramentos tornaram-se possíveis, evidenciando-se um campo fértil para se pensar como o corpo expressa-se no contexto carnavalesco, principalmente em festas nas quais a máscara aparece como uma das condições para o festejo.

Tal anseio investigativo possibilitou identificar a máscara como elemento multifacetário para os foliões que a utilizam para brincar o carnaval veneziano, pois ela está relacionada à ruptura do cotidiano, o que traduz certa liberdade aos que fazem seu uso; ao elemento lúdico, hedonista e de representação teatral, capaz de evocar um brincar de corpos por meio do entretenimento, da sedução e da representação; à construção estética dos sujeitos como personagens principais da festa, o que atribui vigor ao cenário nostálgico da cidade.

Embora cheguemos a essas constatações, outras reflexões acerca da máscara são possíveis, mesmo que não tenham surgido, necessariamente, das entrevistas realizadas com os sujeitos do estudo. Daí constatarmos que a máscara também ocupa papel comercial na cidade, repleta de significados relacionados ao vendável na dimensão turística que vê na máscara o potencial de consumo aliado a outros ingredientes dessa lógica mercadológica. Logo, máscaras acabam por ser fabricadas de forma padronizada para atender a demandas industriais, constituindo-se como experiências uniformizadas 
exigidas por conta do contexto festivo. Tal constatação evidencia o modo como mecanismos são criados com vistas a diluir a tradição veneziana, corroborando processos que culminem com o atendimento aos interesses lucrativos forjados a partir da tradição da cidade.

Por fim, avaliamos que a investigação possibilitou o aporte necessário para se entender a dialética entre corpo e máscara: ora essa relação se expressa pela busca de experiências que correspondam à máscara em seu sentido tradicional; ora ela ocorre a partir da lógica "máscara produto". Tais configurações não se dão desprovidas das tensões constitutivas entre sensível e racional, normativo e transgressivo, lúdico e disciplinado, o que abre espaços para que os sujeitos, na condição de protagonistas, possam buscar a mediação orientadora das suas práticas corporais, transcendendo a racionalidade posta como instrumental rumo à construção de outra racionalidade, pautada pela consciência de seu papel na festa, dos riscos da entrega desmedida ao prazer e ao consumo e da possibilidade de constituir-se como um sujeito de escolhas.

\section{REFERÊNCIAS}

BAKHTINM, M. M. A cultura popular na Idade Média e no Renascimento: o contexto de François Rabelais. Trad. Yara Frateschi. São Paulo: Hucitec, 2010.

BURKE, P. O carnaval de Veneza. In: CUNHA, M. C. P. (Org.). Carnavais e outras f(r)estas. Campinas: Editora da Unicamp, 2002.

BRACHT, V. Educação Física escolar e lazer. In: WERNECK, C. L. G.; ISAYAMA, H. F. (Orgs.). Lazer, recreação e educação física. Belo Horizonte: Autêntica, 2003.

BRANDÃO, C. R. A cultura na rua. Campinas: Papirus, 1989.

BRESSANELLO, A. Il carnevale in età moderna: 30 anni di carnevale a Venezia 1980 - 2010. Veneza: Studio LT2, 2009.

CAILLOIS, R. Os jogos e os homens: a máscara e a vertigem. Tradução de José Garcez Palha. Lisboa: Cotovia, 1990. 
CASTRO JÚNIOR, L. V. Contextualizando e rastreando o tangível na pesquisa Festa e Corpo. In: CASTRO JÚNIOR, L. V. (Org.). Festa e corpo: as expressões artísticas e culturais nas festas populares baianas. Salvador, BA: Edufba, 2014.

FREIRE, J. B. O jogo: entre o riso e o choro. 2. ed. Campinas: Autores Associados, 2005.

GEERTZ, C. A interpretação das culturas. 13 reimp. Rio de Janeiro: LTC, 2008.

HUIZINGA, J. Homo Ludens: o jogo como elemento da cultura. 6 ed. São Paulo: Perspectiva, 2004.

MADDEN, T. F. A history of Venice: queen of seas. Recorded Books, 2010.

PAVIS, P. Dicionário de teatro. Tradução de J. Guinsburg e Maria Lúcia Pereira. 3 ed. São Paulo: Perspectiva, 2011a.

REATO, D. Venezia: uma città in maschera. Fillipi Editore Venezia, 1998.

Le maschere veneziane. Verona: Arsenale, 2001.

ROSA, M. C. Festar na cultura. In: ROSA, M. C.;PIMENTEL, G. G. de A.; QUEIRÓS, I. L. von B. G. de(Orgs.). Festa, lazer e cultura. Campinas, SP: Papirus, 2002.

VASCONCELLOS, L. P. Dicionário de teatro. 6 ed. Porto Alegre, RS: L\&PM POCKET, 2010.

ZORZI, A. La Repubblica del Leone: storia di Venezia. 6 Ed. Millão: Tascabili Bompiani, 2011.

\section{Endereço dos autores}

Vitor Hugo Marani

Universidade Estadual de Maringá

Avenida Colombo, 5790, Bloco 06, sala 12

Jardim Universitário - Maringá - PR

CEP 87020-900

Endereço Eletrônico: vitormarani@hotmail.com

Larissa Michelle Lara

Universidade Estadual de Maringá

Avenida Colombo, 5790, Bloco 06, sala 12

Jardim Universitário - Maringá - PR

CEP 87020-900

Endereço Eletrônico: 1mlara@uem.br 